\title{
A QUALITATIVE EVALUATION OF THE DIDACTIC ACTING OF THE TUTORS INVOLVED IN THE PROGRAM OF TUTORIA IN BIOCHEMISTRY AT UFV
}

\author{
Damasceno, J.D. ${ }^{1}$, Franco, M.W. ${ }^{1}$, Batista, T.A.S., Alves, M.S., Pereira, A.G., \\ Paiva, D.F.O., Trevizano, L.M., Magalhães, R.D.M., Baracat-Pereira, M.C. \\ Programa de Tutoria, Unidade de Apoio Educacional, UFV, Viçosa 36570-000, \\ Viçosa, MG.
}

The Tutorial Program in Biochemistry is part of a Program of Didactic Support at UFV that intends to give academic-pedagogic support to students that arrived to the UFV with deficiency of previous knowledge in basic areas of the sciences. The tutors are under-graduated students chosen by public selection. The present work seeks to evaluate the tutors of the biochemistry area as for the aspects public speaking, didacticism and satisfaction of the tutor and of the students assisted by the program. Two questionnaires were applied, one to the tutors and one to the under-graduated assisted-students. The totality of the tutors answered that the participation in this program contributes professionally by increasing the capacity of relationship in group, dynamism, decisions and organization, helped them to be more extroverted and they felt satisfied to help other people, which characteristics that are more and more appraised in the job market. The evaluation showed also that the ability to express in public developed positively and improved the diction, presenting safety when speaking in public. The tutors also opened your vision on the teaching form in the University, a positive result, considering their positions of student in one public university. 